\title{
Diplomatic strategies of the Patani kingdom in Hikayat Patani: a sociology of literature study
}

Islahuddin ${ }^{a 1^{*}}$, Ku-Ares Tawandorloh ${ }^{\mathrm{b}}$, Sumaiyah Menjamin ${ }^{\mathrm{c} 3}$

Malay Department, Fatoni University, Thailand ${ }^{a, b, c, d}$

islahuddin@fu.ac.th ${ }^{1 *}$; kuares.t@ $@$ ftu.ac.th ${ }^{3}$, sumaivah@,ftu.ac.th ${ }^{3}$

\begin{tabular}{ll}
\hline Informasi artikel & \\
\hline Sejarah artikel: & \\
Diterima: & 8 oktober 202I \\
Revisi: & 25 oktober 202I \\
Dipublikasikan: & 30 oktober 202I \\
\hline
\end{tabular}

ABSTRAK

Hikayat Patani adalah hikayat yang mengisahkan kerajaan Patani dan berbagai strategi diplomasi yang terdapat dalam kerajaan Patani. Tujuan penelitian ini adalah untuk memaparkan berbagai teks yang membahas tentang strategi diplomasi kerajaan Patani dalam Hikayat Patani dengan memakai pendekatan sosiologi sastra. Penelitian ini bersumber data Hikayat Patani. Teknik

Kata kunci:

strategi

diplomasi pengumpulan data menggunakan teknik pembacaan dan pencatatan. Teknik analisis data menggunakan teknik deskriptif kualitatif disertai teori sosiologi sastra. Hasil penelitian menyatakan bahwa strategi diplomasi kerajaan Patani yang terdapat dalam Hikayat Patani, yaitu: I) diplomasi politik dengan Siam; sosiologi sastra 2) diplomasi perang dengan Siam dan Palembang; 3) diplomasi perkawinan dengan Pahang dan Johor; 4) diplomasi perdagangan dengan Cina dan Malacca; 5) diplomasi kekuasaan dengan Kelantan; dan 6) diplomasi keagamaan dengan Pasai. Tambahan pula, hasil penelitian menyatakan bahwa strategi diplomasi kerajaan Patani yang terdapat dalam Hikayat Patani bertujuan untuk mempertahankan dan menjaga kehormatan kerajaan sebagai sebuah kerajaan yang berdaulat serta merupakan cermin masyarakat Patani pada waktu teks tersebut diciptakan.

Key word:

Strategy

Diplomatic

Patani kingdom

Hikayat Patani

Literary of sociology

\section{ABSTRACT}

the Hikayat Patani is a saga that tells of the Patani kingdom and its various diplomatic strategies. This research aims to describe various excerpts discussing the diplomatic strategies of the Patani kingdom in the Hikayat Patani by using a literary sociology approach. The data source of this research was Hikayat Patani. The data collection techniques were reading and noting techniques. The data analysis technique used a qualitative descriptive technique accompanied by a theory of literature of sociology. The results of the study show that diplomatic strategies of the Patani kingdom in Hikayat Patani were: I) political diplomacy with Siam; 2) war diplomacy with Siam and Palembang; 3) marital diplomacy with Pahang and Johor; 4) trade diplomacy with China and Malacca; 5) power diplomacy with Kelantan; and 6) religious diplomacy with Pasai. Moreover, the results of the research show that the diplomatic strategies of the Patani kingdom contained in Hikayat Patani aim to maintain and maintain the honor of the kingdom as a sovereign kingdom and a mirror of Patani society at the time the text was created.

Copyright (C) 2018 Universitas Ahmad Dahlan. All Right Reserved

\section{Introduction}

Hikayat Patani is a saga about the Patani kingdom. A long time ago, the Patani kingdom was a kingdom in a small city in the Southern region of Thailand. The Patani kingdom was also a Malay sultanate, which had full authority, had a big harbor, and was actively engaged in international trade (Yock Fang, 20I I:503). On the other hand, Hikayat Patani is a classic Malay literary work about history, hence, called historical literature. Historical literature mainly focuses on what happened in the palace, the fate of the kingdom, and its legacy, and was printed in the palace's society (Yock Fang, 20I I:433).

It is estimated that Hikayat Patani was written around the $17 \mathrm{t}^{\mathrm{h}}$ century and the early $18^{\text {th }}$ century, I690I730 M. (Bradley, 2009:268). Hikayat Patani is also considered work with literary value, arranged in clarity and harmony in its narrative style (Braginsky, 1998:342). However, Braginsky (1998:342) emphasizes that Hikayat Patani is different from other Malay sagas in that it barely narrates myths, but it explains the establishment of the Patani kingdom, how the king of Patani converted to Islam, and the relationship with other neighboring kingdoms. 
The relationship between the Patani kingdom and its neighboring kingdoms was peaks and valleys. Various diplomatic strategies were conducted by the Patani kingdom to preserve its existence. 'Strategy' refers to the knowledge used to implement national policies of a country related to war and peace (KBBI, 2008). On the other hand, the official relation management between countries is called diplomacy. Thus, diplomatic strategy is a science and a strategy used by the Patani kingdom to manage the relationships with other countries or kingdoms.

The diplomatic strategies of the Patani kingdom can be studied using the literary sociology approach. The study of society, institutions, and social processes is called sociology (Swingewood (I972) in Wiyatmi, 2013:56). Human in society is the object of both sociology and literature study. Meanwhile, how people subjectively and individually appreciate the social life in the society which is observable differentiates both studies. In addition, it is emphasized by Damono (1979:I) that literature research that concerns the social life of the society is called the sociology of literature approach.

Conversely, there are two types of sociology of literature, namely: I) a study concerning the factors beyond the literary work itself which is called the sociology of literature; 2) a study concerning the structure of a literary work and a particular society is called literary of sociology (Swingewood (1972) in Wiyatmi (2013:7-8).

Three categories of sociology of literature are I) the sociology of authors which concerns authorship; 2) the sociology of literature works which concerns the literary works; and 3) the sociology of the readers which concerns the impact of a literary work on its readers (Wellek and Warren (1994) in Damono, 1979:3).

There is three sociology of literature approaches, they are: I) sociology of literature on the relationship between the author and the reader; 2) sociology of literature discussing how literary works reflect the condition of the society; 3) sociology of literature on the relationship between literary works and social values (Ian Watt (I946) in Damono (1979:3). However, this present study focuses on the sociology of literature that becomes the reflection of Patani society in Hikayat Patani.

Previously, Hikayat Patani has been studied using various paradigms, such as I) structural paradigm by A. Teeuw and D.K. Wyatt (1970); Haji Salleh (2010); 2) historical paradigm by Francis R. Bradley (2009); and inter-structural paradigm by Islahuddin and Tawandorloh (2018). Furthermore, is/was chosen because I) Hikayat Patani contains the diplomatic strategy of the Patani Kingdom; 2) Hikayat Patani contains the information from the past which may also be relevant in the present time/condition (Baroroh-Baried, et.al., 1994:2). Therefore, the research question of this study/research is: How are the diplomatic strategies of the Patani Kingdom in Hikayat Patani? This research aims to describe the diplomatic strategies of the Patani kingdom in Hikayat Patani.

\section{Methodology}

This research employed the descriptive qualitative method. Descriptive in that the illustration is systematic, and the relationship among the phenomena studied is revealed in the said method (Nasir, 20II). Moreover, the description is systematic, factual, and accurate, based on the fact, the characteristics of a particular population, and the comprehensive description which is the main aim of a descriptive method (Yusuf, 2007:53). The researcher is the primary instrument of the research (Sugiyono, 2013).

The data source of this research is Hikayat Patani text by A. Teeuw and D.K. Wyatt (1970), published by Martinus Nijhoff (The Hague) and another Hikayat Patani text by Siti Hawa Haji Salleh (2010), published by Balai Bahasa dan Pustaka. The data collection techniques were reading and taking notes. The data were analyzed using the qualitative descriptive technique. The data collected were categorized and analyzed using the sociology of literature. The steps in analyzing the data were I) finding the data; 2) classifying the data; 3 ) describing the data; 4) concluding the data, and 5) presenting the data descriptively.

\section{Result and discussion}

This part of the article discusses the result of the research and the discussion which is the answer to the formulation of the problem, and describes the diplomatic strategy of the Patani kingdom in Hikayat Patani. A timeline has been made before continuing the discussion as follows: 
Table I. The timeline of Hikayat Patani

\begin{tabular}{|c|c|c|c|c|}
\hline No. & $\begin{array}{l}\text { The name of } \\
\text { the event }\end{array}$ & Reign & $\begin{aligned} & H P \text { Teeuw } \\
& \& \mathrm{~W} \text { yatt }\end{aligned}$ & $\begin{array}{ll} & H P \\
\text { Salleh }\end{array}$ \\
\hline I. & $\begin{array}{l}\text { Political } \\
\text { diplomacy with } \\
\text { Siam }\end{array}$ & $\begin{array}{c}\text {-Sultan } \\
\text { Mudaffar Syah } \\
\text {-Sultan } \\
\text { Manzur Syah }\end{array}$ & $\begin{array}{ll}\text { 2I. } & \text {-pg. I6-I7, } \\
& \text {-pg. } 33-34\end{array}$ & $\begin{array}{l}\text {-pg.I0-II, } \\
\text {-pg. } 22\end{array}$ \\
\hline 2. & \begin{tabular}{lr}
\multicolumn{1}{c}{ War } \\
diplomacy with \\
Siam & and \\
Palembang &
\end{tabular} & $\begin{array}{c}\text { - Sultan } \\
\text { Mudaffar Syah } \\
\text { - Raja Ungu } \\
\text { - Sultan } \\
\text { Manzur Syah }\end{array}$ & $\begin{aligned} & \text {-pg.23, } \\
& \text {-pg. } 55, \\
&- \text { pg.58, 28, } \\
& 28-29\end{aligned}$ & $\begin{array}{c}\text {-pg.15, } \\
\text {-pg.37, } \\
\text { I8, I9 }\end{array}$ \\
\hline 3. & $\begin{array}{l}\text { Marriage } \\
\text { diplomacy with } \\
\text { Pahang and Johor }\end{array}$ & $\begin{array}{l}\text {-Raja Ijau } \\
\text {-Raja Ungu }\end{array}$ & $\begin{array}{c}\text {-pg.5I-52. } \\
67,67^{-p g .55,66-}\end{array}$ & $\begin{array}{c}\text {-pg.34 } \\
45,45^{\text {-pg.36-37, }}\end{array}$ \\
\hline 4. & \begin{tabular}{l}
\multicolumn{1}{c}{ Trade } \\
diplomacy with \\
China and Malacca
\end{tabular} & $\begin{array}{l}\text {-Sultan } \\
\text { Ismail Syah }\end{array}$ & $84 \quad$-pg.I2, I3, & -pg.7, 8, 57 \\
\hline 5. & \begin{tabular}{l}
\multicolumn{2}{c}{ Religion } \\
diplomacy with \\
Pasai
\end{tabular} & $\begin{array}{l}\text {-Sultan } \\
\text { Ismail Syah }\end{array}$ & -pg.IO-I I, & -pg.6-7, I0 \\
\hline 6. & \begin{tabular}{l}
\multicolumn{2}{c}{ Power } \\
diplomacy \\
Kelantan
\end{tabular} & \begin{tabular}{c}
\multicolumn{2}{c}{-Raja } \\
Kuning \\
-Raja Bakal
\end{tabular} & -pg.75 & -pg.50-5I \\
\hline
\end{tabular}

\section{Political Diplomacy with Siam}

The first diplomatic strategy of the Patani kingdom is political diplomacy with the Siam kingdom (Ayutia). This strategy was conducted when Sultan Mudaffar Syah visited Siam (Ayutia). The visitation was done to keep a good relationship between both kingdoms, as written in the excerpt below.

Setelah berapa hari baginda berlayar itu maka baginda pun sampailah Ayutia. Arakian maka orang kuala pun segera bersembahkan pada bakelang mengatakan, "Raja Patani datang hendak mengadap Duli Bercau Yang Maha Mulia." Maka bakelang pun dengan segeranya masuk bersembahkan ke bawah Duli Bercau. Setelah Bercau mendengar sembah bakelang itu, maka Bercau pun terlalu sukacita, lalu menitahkan segala apya opra' menyambut Sultan Mudaffar Syah itu. Syahadan maka baginda pun naiklah mengadap Bercau dengan persembahannya yang indah-indah (Teeuw \& Wyatt, 1970:16-I7; Haji Salleh, 20I0:I0-I I).

The excerpt above explains the Patani kingdom's first visit to Siam (Ayutia) under the reign of Sultan Mudaffar Syah. Giving gorgeous presents during the visit was one of the diplomacy strategies of the Patani kingdom to keep a good relationship with the Siam kingdom(Ayutia).

Moreover, there was Sultan Mudaffar Syah's second visit to the Siam kingdom. The Siam kingdom gave a warm welcome upon the visit of the Patani kingdom troupe. Read the excerpt below.

Hatta antara berapa hari baginda di laut maka baginda pun sampailah ke Siam. Setelah keesokan harinya maka segala apya opra pun datanglah, dititahkan oleh Bercau menyambut baginda. Arakian maka baginda pun naiklah mengadap Bercau dengan persembah pun terlalu banyak seperti adat segala raja-raja yang meminang. Maka Bercau pun terlalu sukacita melihat baginda datang itu serta dengan kasih mestanya seperti mana putera Bercau yang benar, demikianlah laku Bercau itu dan diberi duduk pun hampir dengan pintu Kota Wang (Teeuw \& Wyatt, 1970:2I; Haji Salleh, 20I0:13).

The excerpt explains that the Patani kingdom was under the governance of Sultan Mudaffar Syah when they visited Siam, giving gorgeous presents and in turn, the Siam kingdom welcomed them happily and gave their trope a place to sleep in an area close to the throne of Siam kingdom.

In addition, the third visit of the Patani kingdom was done by their representative, Seri Agar. The diplomatic strategy of the Patani kingdom in their third visit aimed to rebuild the relationship between the Patani kingdom and the Siam kingdom that had been tense after a war between the two kingdoms broke out. It is illustrated in the excerpt below. 
Hatta berapa hari di laut maka Seri Agar pun sampailah ke Siam. Maka dipersembahkan orang kepada bakelang. Maka bakelang pun segera masuk mengadap Bercau persembahkan utusan dari Patani datang hendak mengadap Duli Yang Maha Mulia. Maka Bercau pun terlalu sukacita mendengar sembah bakelang mengatakan utusan Patani datang itu. Maka titah baginda Bercau kepada bakelang, "Suruhlah pergi sambut perahu utusan Patani itu, bawa mudik dengan segeranya." (Teeuw \& Wyatt, 1970:33-34; Haji Salleh, 2010:22).

The excerpt explains that the Patani kingdom did a diplomacy strategy for the third time to build a good relationship between the two kingdoms because before their relationship became tense, they had had a war for the first time. Thus, their visit was welcomed warmly by the Siam kingdom.

The diplomatic relationship between the Patani kingdom and the Siam kingdom is a mirror of what happened to the Patani kingdom. Their diplomatic relationship went through hot and cold, harmonious at times and tense at the other times. The diplomatic relationship between the two kingdoms begun since Sultan Mudaffar Syah made a visit to Siam (Ayutia). During that time, Sultan Mudaffar Syah was dissatisfied with how the Siam kingdom welcomed them. After that, Sultan Mahmud Syah continued the diplomatic relationship to keep the good relationship between the two kingdoms (Abd. Rahman, 2018:9).

However, the Patani Kingdom had formed political diplomacy with the Siam kingdom since a long time ago, proved by their visit to the Siam kingdom. Moreover, the Patani kingdom attacked Siam for the first time in I563 when the Siam kingdom was not yet stable after losing in the war with another kingdom (Hayimasae, 2009).

According to the results of the analysis of several texts, it can be concluded that the political diplomacy strategy of the Patani kingdom was in the form of visits to the Siam kingdom, as written in Hikayat Patani, to set up a more harmonious relationship among them. The statement is supported with data saying that the relationship between two countries is always dynamic and that strategies are needed to stabilize it, by the Patani kingdom's visit to the Siam kingdom. Moreover, the political diplomacy strategy is also a reflection and reality of the Patani kingdom in establishing a harmonious relationship with the Siam Kingdom.

\section{War diplomacy with Siam and Palembang}

The second diplomatic strategy of the Patani kingdom is war diplomacy with Siam and Palembang. The first war diplomacy was carried through when Sultan Mudaffar Syah was in Siam (Ayutia) and was not satisfied with how the Siam kingdom welcomed them, and saw a chance in taking over Siam (Ayutia) when the Siam kingdom was in conflict. The war diplomacy strategies are presented in the excerpt below.

Setelah didengar oleh segala menteri hulubalang Bercau dengan segala rakyatnya bunyi gendang raya itu, maka segala isi negeri itu pun berhimpunlah kesemuanya; kepada sangkanya Bercau itu ada lagi dalam mahligai itu, lalu dilanggarnya Kota Wang itu berkeliling. Maka segala menteri hulubalang dan rakyat Patani pun keluar dari dalam Kota Wang itu lalu bertikam dengan rakyat Siam terlalu ramai. Maka segala rakyat Patani pun patah perangnya, lalu undur masuk ke dalam Kota Wang pula. Maka pintu kota itu pun ditutupnya (Teeuw \& Wyatt, 1970:23; Haji Salleh, 2010:I5).

The excerpt explains when Sultan Mudaffar Syah visited the Siam (Ayutia) kingdom and was not satisfied with how they were welcomed, and saw a big conflict in the said kingdom, Sultan Mudaffar Syah initiated to attack the Siam (Ayutia) kingdom, thus, a big war broke out between the two kingdoms. The war lasted several days until the Patani troupe was cornered and resulting in the death of Sultan Mudaffar Syah and a loss for the Patani kingdom.

On the other hand, the war diplomacy with Siam was done when Apya Deca (Patthalung) was angry and disappointed because his engagement with Putri Kuning was called off by the Patani kingdom. Apya Deca asked for the Siam kingdom's help to attack the Patani kingdom. Read the excerpt below:

Arakian maka khabar itu pun dipersembahkan orang kepada Apya Deca. Maka Apya Deca pun terlalu marah lalu pergi minta tolong kepada bakelang menyembah Bercau hendak menyerang Patani. Arakian maka Apya Deca pun dibawa bakelang masuk mengadap Bercau. Syahadan maka bakelang pun berdatang sembah kepada Bercau seperti kehendak Apya Deca itu. Maka Bercau pun memberi titah kepada bakelang suruh berlengkap rakyat dan senjata dan apya opra dan segala akun awamin mengantarkan Apya Deca ke Patani. Dan suatu cetera rakyat Siam itu seketi banyaknya dan suatu kaul pula delapan laksa. Syahadan pada masa itu Siam belum lagi tahu berperahu di laut, jikalau berapa banyak pun berjalan itulah (Teeuw \& Wyatt, 1970:55; Haji Salleh, 2010:37).

The excerpt explains that another war between the Patani kingdom and the Siam kingdom broke out when Apya Deca (Patthalung) was furious and asked for the Siam kingdom's help to attack the Patani kingdom. The Patani people got ready to put up a defense after Apya Deca (Patthalung) and the Siam kingdom's attack.

The war continued, and the Patani kingdom formulated an effective war strategy in which they took away the food supplies of both Apya Deca (Patthalung) and the Siam kingdom's army resulting in those soldiers died of hunger, as written in the excerpt below. 
Hatta dengan demikian tujuh hari juga Apya Deca duduk di Patani itu, maka segala hulubalang Siam pun kembalilah dengan sebab kelaparan segala rakyatnya itu, dari kerana pada masa itu banyak orang Patani masuk makan nasi bersama-sama dengan Siam itu tiada dilihatnya (Teeuw \& Wyatt, 1970:58; Haji Salleh, 2010: 38-39).

The excerpt above tells how the war strategies of the Patani kingdom were quite effective during the war that lasted for 7 days. They took away the food supplies of both Apya Deca (Patthalung) and the Siam kingdom's army, so that they got starved and, thus, lead to the victory of the Patani kingdom.

The second war diplomacy was used against Palembang when the Palembang kingdom attacked the Patani kingdom. The Palembang kingdom assumed that the Patani kingdom, which had no male king at that time, was a weak kingdom. Accordingly, they sent Kiai Badarto to attack the Patani kingdom. Read the excerpt below.

Hatta maka khabar itu pun sampailah ke Palembang. Maka sultan Palembang pun menyuruhkan penggawanya yang bernama Kiai Badar itu menjarah ke Patani membawa rakyat ada seleksa banyaknya. Setelah Kiai Badar sampai ke bandar Patani, maka Kiai Badar pun peranglah dengan orang Patani, ada lima hari lima malam Kiai Badar perang itu, tiada juga dapat naik ke darat. Berapa-berapa dikuatnya hendak naik ke pantai bandar itu, tidak dapat juga. Maka Kiai Badar pun kembalilah (Teeuw \& Wyatt, I970:28; Haji Salleh, 20I0:18).

The excerpt illustrates when the Palembang kingdom heard the news about the Patani kingdom that had lost their king, they asked Kiai Badar to attack them. However, the war was countered by the Patani kingdom, and Kiai Badar failed in taking over Patani and had to go back to Palembang with nothing.

After the failure of Kiai Badar in conquering the Patani kingdom, the Palembang kingdom was in a rage and sent Kiai Kelasang to carry out another attack on Patani as explained in the excerpt below.

Arakian maka Kiai Kesalang pun dititahkan sultan Palembang menyerang Patani membawa rakyat ada seketi banyaknya. Setelah Kiai Kelasang sampai ke Patani maka Kiai Kelasang pun peranglah dengan orang Patani lari naik menjarah ke bandar. Maka segala rakyat Patani pun patahlah perangnya lalu undur masuk ke dalam kota. Maka diturut oleh orang Palembang hingga sampai ke padang di hadapan pintu gerbang itu. Maka dilawan oleh orang Patani dari dalam kota (Teeuw \& Wyatt, 1970:28-29; Haji Salleh, 2010:19).

The excerpt tells that even though the Palembang kingdom sent Kiai Kelasang to attack for the second time to conquer the Patani kingdom, they were, again, countered by the Patani kingdom. Therefore, Kiai Kelasang failed in conquering the Patani kingdom and had to go back to Palembang with nothing.

The war diplomacy strategy of the Patani kingdom illustrates the mirror and the reality of the Patani Kingdom. Moreover, the war diplomacy strategy was carried out to defend the sovereignty of the kingdom. The first war of the Patani kingdom was against the Siam kingdom due to Sultan Mudaffar Syah's dissatisfaction when he visited the Siam (Ayutia) kingdom so that Sultan Mudaffar Syah attacked them in the next visit to seek revenge in I534 M (Abd. Rahman, 2018:9).

The war continued until the Patani kingdom was ruled by Raja-Raja Pelangi and the next one (Abdul Aziz, 2015:2). After the fourth time the Siam kingdom failed in conquering the Patani kingdom, they finally succeeded in the reign of Sultan Muhammad (1774-1785 M.). The army from Siam defeated and conquered the Patani kingdom so that the Patani kingdom was ruled by the governance of Siam-Thai in Bangkok (Abd. Rahman, 2018:10; Abdul Aziz, 2015:2).

Along these lines, Hayimasae (2009) states that the war between Patani and Siam broke out I2 times. In the first war, Patani attacked Siam in I563. After that, the Siam kingdom attacked Patani seven times in I603, I632, I634, I678, I709, and I786, until finally, they succeeded in conquering the Patani kingdom. Next, Patani attacked the Siam kingdom five times in 1789, 1808, 1832, I838, and 1848. However, the attacks were successfully countered by the Siam kingdom resulting in Patani kingdom becoming a part of the Siam kingdom. Moreover, Aziz Yaacob (2012) states that the Siam kingdom attacked Patani in the reign of governance of Raja Hijau (1603), Raja Ungu (1632, I633), and Raja Kuning (1638). After the death of Raja Kuning, in I786, the Siam kingdom attacked the Patani kingdom again and succeeded in conquering the Patani kingdom under their reign.

According to the analysis result of several texts, it can be concluded that the war diplomatic strategy of the Patani kingdom implemented to Siam and Palembang was written in Hikayat Patani and aimed to protect the sovereignty and honor of the Patani kingdom. Additionally, data were saying that the war diplomatic strategy was carried out by the Patani kingdom to protect the sovereignty and honor of the Patani kingdom. On the other hand, the war's diplomatic strategy was a reflection and reality of Patani kingdom's people in countering the war with the Siam kingdom.

\section{Marriage diplomacy with Pahang and Johor}

The third diplomatic strategy employed by the Patani kingdom was marriage diplomacy with Pahang and Johor. The first marriage diplomacy with Pahang was conducted when Raja Ungu married the king of Pahang. 
The marriage aimed to support a good relationship between the two kingdoms, as well as becoming a token of the equal relationship with other Malay kingdoms, especially the Pahang kingdom. After the passing of the king of Pahang, Raja Ungu came back to Patani as mentioned in the excerpt below.

Syahadan maka khabar raja Pahang pun sudah mati maka Phra Cau pun menyuruhkan laksmana dengan pegawai hulubalang berlengkap pergi menyambut adinda baginda yang di Pahang itu. Setelah sudah lengkap maka laksamana pun masuk persembahkan Phra Cau, lalu bermohon turun ke perahu dan surat pun diarak orang turun ke perahu. Setelah sudah laksamana menerima surat itu maka laksamana dengan segala hulubalang yang dititahkan itu pun belayarlah (Teeuw \& Wyatt, I970:5I-52; Haji Salleh, 2010:34).

The excerpt explains that the marriage diplomacy employed by the Patani kingdom was carried through by marrying off Raja Ungu to the king of Pahang to maintain a good relationship between the two kingdoms. However, when the king of Pahang passed away, Raja Biru ordered an admiral to pick Raja Ungu up and bring her back to the Patani kingdom.

The second marriage diplomacy of the Patani kingdom was with the Johor kingdom. When Raja Ungu was bestowed with the Malay title, Syah Alam, she married off her daughter, Putri Kuning, to Yang Dipertuan Johor. The marriage was not without conflict as Putri Kuning was previously engaged to Apya Deca (Patthalung). However, Raja Ungu continued the marriage to improve the relationship between the Patani kingdom and the Johor kingdom which used to be disharmonious as written in the excerpt below.

Hatta antara berapa bulan maka Raja Kuning pun dipersuamikan oleh Syah Alam dengan Yang Dipertuan Johor (Teeuw \& Wyatt, 1970:55; Haji Salleh, 2010:36-37).

The excerpt tells that one of the diplomacy strategies of the Patani kingdom was marriage diplomacy, which is the marriage between Yang Dipertuan Johor and Raja Kuning. This marriage was the diplomatic strategy employed by Raja Ungu to improve the relationship between the Patani kingdom and the Johor kingdom that used to be enemies.

The marriage relationship between Raja Kuning and Yang Dipertuan Johor did not last long because had an affair. After Raja Kuning knew about the affair, Yang Dipertuan Johor went back to Johor but left her mother in Patani as written in the excerpt below.

Hatta maka Yang Dipertuan pun sampailah ke Sai, maka bendahara Sai pun persembahkan perahu dua buah dengan beras bekalan. Maka Yang Dipertuan pun turunlah ke perahu lalu belayar kembali ke Johor dan bondanya tinggal di Patani kerana Yang Dipertuan tiada dapat masuk ke dalam negeri itu (Teeuw \& Wyatt, 1970:66-67; Haji Salleh, 2010:45).

The excerpt shows that after the affair of Yang Dipertuan Johor was known to Raja Kuning, Yang Dipertuan Johor departed from Patani to Johor and left her mother who was still in Patani.

The betrayal of Yang Dipertuan Johor towards Raja Kuning angered her, yet she was still gentle by asking Raja Lela to go to Johor, to take the mother of Yang Dipertuan Johor back to her homeland, as stated in the excerpt below.

Hatta antara berapa bulan maka Phra Cau pun berbicara hendak menyuruh mengantarkan bonda Yang Dipertuan itu, maka seorang pun tiada bercakap. Arakian maka Phra Cau pun menitahkan memanggil Raja Lela di Kandang Kerbau (Teeuw \& Wyatt, I970:67; Haji Salleh, 2010:45).

The excerpt explains that when the mother of Yang Dipertuan Johor lived in Patani, Raja Kuning still treated her kindly by ordering Raja Lela to send her back to Johor to keep a good relationship between the two kingdoms.

The marriage diplomacy strategy of the Patani kingdom aimed to establish a good relationship and show the sovereignty between the two kingdoms as the mirror and reality happened in the Patani kingdom. Similarly, there were data mentioning that the marriage diplomacy strategy between the Patani kingdom and the Pahang kingdom aimed to set up a good relationship between the two kingdoms. Meanwhile, the marriage diplomacy strategy between the Patani kingdom and the Johor kingdom aimed to improve the relationship between the two countries which used to be enemies (Shahul Hamid dan Yaapar, 2015:47).

Moreover, Hayimasae (2009) adds that the marriage diplomacy strategy of the Patani kingdom was carried out by marrying Raja Ungu (I624-I635) to Sultan Pahang, Sultan Abdul Ghafur. After that, in I636 they did the marriage diplomacy by marrying off Raja Kuning to Putera Johor to help them during the war with the Siam kingdom.

According to the analysis of several excerpts, it can be concluded that the marriage diplomacy of Patani kingdom with the kingdoms of Pahang and Johor in Hikayat Patani aimed to keep a good relationship between two Malay kingdoms. Moreover, there is another data saying that the marriage diplomacy carried through in the Malay land was the strategy of the Patani kingdom to set up a good relationship with another Malay kingdom 
that used to be enemies. On the other hand, the marriage diplomacy strategy was a reflection and reality of the people of the Patani kingdom in strengthening the sovereignty of their kingdom.

\section{Trade Diplomacy with China and Malacca}

The fourth diplomatic strategy of the Patani kingdom is trade diplomacy with China and Malacca. The first one, the trade diplomacy with China was carried out when Patani became one of the international harbors for/and trading which was brimming with traders coming from various countries, one of which is China. Read the following excerpt.

Hatta antara berapa tahun lamanya maka datang sebuah wangkang Cina, lain daripada adat purbakala persembahnya itu, ada sebuah peluru batu, besarnya ada seperti bakul muat delapan gantang (Teeuw \& Wyatt, 1970:12; Haji Salleh, 2010:7).

The excerpt explains that one of the diplomatic strategies of the Patani kingdom was international trade, in which they opened a path for international trade, including for Chinese traders who brought various commodities to the Patani kingdom.

Aside from the trade diplomacy with China, the Patani kingdom also set up the second trade diplomacy with Malacca traders, as written in the excerpt below.

Syahadan dalam tiga tahun itu datanglah sebuah selub dari Melaka berniaga membawa dagangan terlalu indah (Teeuw \& Wyatt, I970:13; Haji Salleh, 2010:8).

The excerpt explains that the second trade diplomacy, with Malacca, happened when the Patani kingdom opened international trade diplomacy, and traders from various countries came to the kingdom, including those from Malacca. The traders from Malacca brought in various exquisite commodities for the Patani people. The traders, then, bought various corps from the people of the Patani kingdom.

Since the Patani kingdom became an international harbor, the Patani kingdom became a prosperous kingdom in which people live safely and healthily. Furthermore, the illustration of the kingdom's prosperity was clear from how no one wanted to take the golds and silvers put all over the place, as illustrated in the excerpt below.

Kepada masa itulah dalam daerah negeri Patani sangat senang dan sentosanya segala rakyat. Jikalau (tiada) datang daripada berlayar, tatkala sampai perahu itu ke labuhan bandar Patani ini tiadalah lagi ditunggu perahu di labuhan itu. Jikalau jenis emas perak sekalipun tiadalah siapa-siapa yang mengambil dia (Teeuw \& Wyatt, 1970:84; Haji Salleh, 2010:57).

The excerpt tells that the Patani kingdom became one of the most prosperous kingdoms in Malay because they had an international harbor raising the economy of the Patani people. This condition was illustrated as even if anyone put golds and silvers on any place, no one would take them.

The international trade diplomacy strategy of the Patani kingdom was the mirror and reality that happened in the Patani kingdom under the reign of Raja Ijau (Hijau). On the other hand, the fall of Malacca to Portugal in I5I I M forced some Islamic traders to move to the Patani harbor. Consequently, Raja Ijau was being careful not to let Patani harbor experience the same thing as the Malaka harbor (Shahul Hamid dan Yaapar, 20I5:4I).

Similarly, the peak of success of the Patani kingdom happened in the 17th century. The Patani kingdom ruled the harbors and could compete with other countries, such as Pahang, Johor, and other kingdoms in the nation. The Patani kingdom also ruled the gulf of Siam and the South China sea, hence, they become a well-known center of trades in South East Asia. (Razak Mahmud and Fathy al-Fatani, 20I8:I5I-I52). Abdul Aziz (20I5) adds that the Patani kingdom had established international trade relationships with various countries in the world, including China and Malacca.

Based on the analysis of those excerpts, it can be concluded that the strategies for trade diplomacy employed by the Patani kingdom on China and Malacca were written Hikayat Patani and aimed to improve the economy of the Patani kingdom and their people. Similarly, there was data saying that the trade diplomacy strategy employed by the Patani kingdom aimed to improve the economy of the kingdom as well as the people. Trade diplomacy strategy was the reflection and reality of the Patani kingdom in setting up international trades.

\section{Religious Diplomacy with Pasai}

The fifth diplomatic strategy of the Patani kingdom is religious diplomacy with Pasai. This diplomacy was conducted when the first Patani king, Sultan Ismail Syah, converted to Islam under the teaching of a man from Pasai, Syekh Said. Read this excerpt.

Setelah Syekh Said itu datang, maka raja pun sangatlah memuliakan Syekh Said itu. Maka titah baginda, "Adapun hamba memanggil tuan hamba ini, kerana janji hamba dengan tuan hamba ini hendak masuk agama Islam itulah.” Setelah Syekh Said mendengar titah raja demikian itu, maka Syekh Said pun segera mengucup tangan raja 
itu, lalu dijunjungnya. Sudah itu diajarkanlah kalimat syahadat oleh Syekh demikian bunyinya, "Asyhadu an la ilaha illaLlah waasyhadu anna Muhammadan rasululLah.” Maka raja pun kararlah membawa agama Islam. Setelah sudah raja mengucap kalimat syahadat itu, maka Syekh Said pun mengajarkan kalimat syahadat kepada segala menteri hulubalang dan rakyat yang ada hadir itu pula (Teeuw \& Wyatt, I970:I0-I I; Haji Salleh, 2010:6-7).

The excerpt above explains that the religious diplomacy with Pasai was conducted when the first Patani king had to keep a promise to change his religion to Islam after his illness was cured by a Pasai man, Syekh Said. The process for the Patani kingdom to change their religion to Islam was not easy. The king had to fall sick three times until he finally changed his religion into Islam by professing his faith (shahada) under the teaching of Syekh Said.

Moreover, religious diplomacy with the Pasai kingdom was conducted when discussing with another man from Pasai, Syekh Safiuddin related to the condition and development of Islam in Patani, and the strategy to be a good Muslim, which is by building a mosque, as written in the excerpt below.

Hatta antara berapa lama maka datang pula seorang Pasai bernama Syekh Safiuddin. Maka Syekh Safiuddin pun berbuat rumah di padang di luar pintu gerbang itu. Arakian maka Syekh Safiuddin pun dipanggil raja bertanyakan perintah agama Islam. Maka sembah Syekh Safiuddin, "Adapun negeri Islam itu mahulah ada sebuah masjid tempat segala rakyat menyembah Allah Taala, maka nyatalah agama Islam; dan jikalau tiada masjid itu jua tiadalah kenyataan agama Islam itu." (Teeuw \& Wyatt, 1970:15; Haji Salleh, 2010:I0).

The excerpt of the text recounts that the religious diplomatic strategy was conducted by the Patani kingdom through embracing Pasai preachers in the Patani kingdom related to the development of Islam. The man from Pasai, Syekh Safiuddin, suggested building a mosque as the center of Islamic events and education in Patani.

The religious diplomacy conducted by the Patani kingdom was the reflection and the reality of what happened in Patani during the reign of Sultan Ismail Syah, the first king of Patani to convert to Islam. Thus, the Patani kingdom supported to build of the mosque as the center of the development of Islam. After that, in the reign of Raja Ijau Kerisek mosque, was built using red bricks, different from the other mosques which were generally built using woods (Shahul Hamid dan Yaapar, 2015:46). Patani became the center for Islamic education marked by the vast amount of people from various countries who came to learn Islam and by the establishments of Pondok (traditional Islamic boarding school) in Patani (Shahul Hamid dan Yaapar, 2015:46).

The establishment of Islamic schools got full supports from the Patani kingdom that it brought rapid development in the said area of concern. One among the first established Islamic school was Pondok Pauh Bok built by al-Syeikh Muhammad Jailani al-Jarimi al-Fatani. The school was in Narathiwat province, close to Teluk Manok village where Masjid Wadi Husin, the oldest mosque in Thailand, was built (Abd. Rahman, 2018:II). Additionally, there was a preacher in Pattani province named Faqih Wan Musa Bin Muhammad Saleh al-Laqihi who opened another Islamic school or Pondok in Sena village, Patani which was the first Islamic school in Patani (Fathy al-Fatani, 20I3:5).

Meanwhile, Suryadi (2017) states that Islam in Patani was brought in in I 457 by a preacher from Pasai, proved by the similarity of tombstones of the king of Patani and Pasai which was the Aceh Darussalam tombstone, influenced by the Pasai kingdom. On the other hand, Hayimasae (2009) adds that the spread of Islam in Patani was brought in by a Syeikh of Arab descent named Syeikh Ali Abdullah, who also spread Islam to Kelantan.

Based on the analysis of the excerpts, it can be concluded that the religious diplomacy strategy was conducted by the Patani kingdom towards Pasai people as written in the Hikayat Patani aimed to guide the Patani king to embrace and make advancement in the spread of Islam in Patani. Similarly, there was data illustrating that the religious diplomacy strategy of the Patani kingdom aimed to aid the spread of Islam in Patani by involving people from Pasai as their preachers in the Patani kingdom. The strategy was the reflection and reality of the people of the Patani kingdom in spreading Islam in their areas.

\section{Power diplomacy with Kelantan}

The sixth diplomatic strategy of the Patani kingdom was power diplomacy with the Kelantan kingdom. This diplomacy was conducted after Raja Kuning had passed away and they had no one to continue the reign of the Patani kingdom as illustrated in the excerpt below.

Setelah berapa lamanya Phra Cau di atas takhta kerajaan maka Phra Cau pun gering lalu mangkat. Maka mayat Phra Cau pun dikuburkan oranglah. Dan Phra Cau itulah dipanggil orang Marhum Besar sebab kerana bersuamikan Yang Dipertuan Besar Johor.

Maka sekalian menteri pun berhimpunlah berbicara kerana tiadalah lagi salasilah raja yang hilir dari hulu itu (Teeuw \& Wyatt, 1970:75; Haji Salleh, 2010:50). 
The excerpt explains that the power diplomacy was conducted by the Patani kingdom towards the Kelantan kingdom after Raja Kuning had passed away without having any heirs. Hence, the ministers discussed doing power diplomacy to avoid power vacuum in the sovereignty of the Patani kingdom.

The power diplomacy was conducted by handing over the power of Patani kingdom to the Kelantan kingdom. Raja Bakal, the king of Kelantan, was asked to fill in the vacant position in the Patani kingdom as written in the excerpt below.

Sebermula ada seorang asal anak raja Kelantan duduk di Teluk, Raja Bakal namanya. Maka Raja Bakal itulah ditabalkan orang. Itulah asal anak-anak raja Kelantan yang kerajaan di Patani ini (Teeuw \& Wyatt, 1970:75; Haji Salleh, 20I0: 5I).

The excerpt illustrates that there was a power vacuum in the Patani kingdom after the passing of Raja Kuning, which led to the ministers asking for Raja Bakal, the king of Kelantan, to fill in the position and lead the Patani kingdom alongside the Kelantan kingdom.

The power diplomacy carried out by the Patani kingdom was the reflection and the reality of what happened in the Patani kingdom when they faced a power vacuum. The Patani kingdom was led by the Kelantan kingdom in I65I M after the passing of Raja Kuning (Razak Mahmud and Fathy al-Fatani, 2018:I58). Kelantan was previously an area colonized by the Patani kingdom was ordained to rule the Patani kingdom to avoid a power vacuum (Syukri, 1985:36). Hence, without a king who can lead the government well, and barrages of attack from the Siam kingdom caused the fall of the Patani kingdom to the rule of the Siam kingdom (Fathy al-Fatani, 1994:71-72).

Hayimasae (2009), however, states that Patani and Kelantan were an area that was merged for I3I years. The merging of the two areas aimed to counter the attack from the Siam kingdom. Similarly, Abd Rahmad and Mohamad Shukri (20II) add that in the I7th century, Patani, Kelantan, and Terengganu belonged to the same area under the same political governance named the Patani Besar country.

Based on the analysis of the texts, it can be concluded that the power diplomacy was conducted by the Patani kingdom to the Kelantan kingdom written in Hikayat Patani aimed to avoid power vacuum and to defend the Patani kingdom. Therefore, the war diplomacy was a reflection and reality of the people of the Patani kingdom in defending their sovereignty.

\section{Conclusion}

The diplomatic strategies of the Patani kingdom in Hikayat Patani, were: I) political diplomacy with Siam aimed to establish a harmonious relationship between the two kingdoms; 2) war diplomacy with Siam and Palembang aimed to defend their sovereignty and honor; 3) marriage diplomacy with Pahang and Johor aimed to establish a good relationship with other Malay kingdoms that used to be enemies; 4) trade diplomacy with China and Malacca aimed to improve their economy and their people's prosperity; 5) religious diplomacy with Pasai aimed to support the spread of Islam in Patani by involving Pasai people as the preachers in their kingdom, and 6) power diplomacy with Kelantan aimed to avoid power vacuum and maintain their reign.

Furthermore, the result of this research shows that the diplomatic strategies of the Patani kingdom written in Hikayat Patani aimed to defend and keep the honor of the Patani kingdom as a sovereign kingdom and as a reflection of the people of the Patani kingdom during the time of the writing of the text.

\section{Acknowledgment}

The researchers thanked the lecturers of the Bahasa Melayu department of Fatoni University (FTU), Thailand as their affiliated institution. The researchers also thanked the redaction of Bahastra for their suggestion and input in the writing of this article draft.

\section{References}

Abd Rahman, N. N., \& Mohamad Shukri, M. N. (201I). Hubungan Rentas Sempadan dan Pengaruhnya Terhadap Pembentukan Pemikiran Hukum Islam di Kelantan (Cross-Border Relations and Its Influence on Formation of Islamic Legal Thoughts in Kelantan). Journal of Al-Tamaddun. Vol. 6 (I), 5I-73. Retrieved from https://ejournal.um.edu.my/index.php/JAT/article/view/8545.

Abd. Rahman, Hamdan. (2018). Penggunaan Bahasa Melayu dalam Naskhah Melayu Patani. Kuala Lumpur: Dewan Bahasa dan Pustaka.

Abdul Aziz, Sohaimi. (2015). Malay Pattani Conflicts with Thailand Authority: A Rhetoric Strategic Review of Web Sites. Melayu: Jurnal Antarabangsa Dunia Melayu, [S.1.], v. 8, n. 2, p. 257-287. Available at: $<$ http://jurnal.dbp.my/index.php/Melayu/article/view/449I. 
Aziz Yaacob, Che Mohd. (2012). Asimilasi Bangsa Melayu di Patani: Keberkesanan Dasar dan Survival Budaya Minoriti. Jebat: Malaysian Journal of History, Politics \& Strategic Studies. Vol. 39 (I), 98-I25.

Baroroh-Baried, Siti et.al. (1994). Pengantar Teori Filologi. Yogyakarta: Badan Penelitian dan Publikasi Fakultas (BPPF) Seksi Filologi, Fakultas Sastra UGM.

Bradley, F. (2009). Moral Order in a Time of Damnation: The "Hikayat Patani" in Historical Context. Journal of Southeast Asian Studies, 402), 267-293. Retrieved March I4, 202I, from http://www.jstor.org/stable/2775I564.

Braginsky, V. I. (1998). Yang Indah, Berfaedah, dan Kamal: Sejarah Sastra Melayu dalam Abad 7-19. Jakarta: Indonesian-Netherlands Cooperation in Islamic Studies (INIS).

Damono, Sapardi Djoko. (1979). Sosiologi Sastra: Sebuah Pengantar Singkat. Jakarta: Pusat Pembinaan dan Pengembangan Bahasa.

Departemen Pendidikan Nasional. (2008). Kamus Besar Bahasa Indonesia. Jakarta: Pusat Bahasa.

Fathy al-Fatani, Ahmad. (1994). Pengantar Sejarah Patani. Alor Setar: Pustaka Darussalam.

Haji Salleh, Siti Hawa. (2010). Hikayat Patani. Kuala Lumpur: Dewan Bahasa dan Pustaka.

Hayimasae, Numan. (2009). Jaringan 'Ulama Patani Dengan Utara Semenanjung Tanah Melayu Abad Ke-I8 dan Ke-19. Petsatuan Sejarah Malaysia.. http://myrepositori.pnm.gov.my/handle/I23456789/3654.

Islahuddin \& Ku-Ares Tawandorloh. (2018). Transformasi dalam Hikayat Patani: Kajian Intertekstual Julia Kristeva. Prosiding Seminar Antarabangsa Memartabatkan Bahasa Melayu/Indonesia ASEAN ke-4. Pattani: 24-25 November 2018.

Nasir, Moh. (20I I). Metode Penelitian. Jakarta: Ghalia Indonesia.

Razak Mahmud, Abdul dan Ahmad Fathy Al-Fatani. (2018). Kelantan-Patani: Ulama' dan Intelektualisme Melayu Wilayah Timur. Kelantan: Majlis Agama Islam dan Adat Istiadat Melayu Kelantan.

Shahul Hamid, Mohamed Nazreen Bin dan Md. Salleh Yaapar. (2015). Sejarah Kehebatan Pemerintahan Raja Perempuan Patani dalam Novel Ratu-ratu Patani. Prosiding Diskusi Karya Patani. 28 Mei 2015, Bilik Persidangan Bangunan C23, Pusat Pengajian Sains Kemasyarakatan. Penang: Universiti Sains Malaysia.

Sugiyono. (2010). Metode Penelitian Pendidikan Pendekatan Kuantitatif, Kualitatif, dan R\&D. Bandung: Alfabeta.

Suryadi, S. (2017). Islam in South Thailand: Acculturation of Islam in the Malay Culture. Falasifa : Jurnal Studi Keislaman. Vol. 8(I), I79-194. https://doi.org/I0.36835/falasifa.v8iI.46.

Syukri, Ibrahim. (1985). History of the Malay Kingdom of Patani (translated by Conner Bailey and Jhon N. Miksic). Athens: Ohio University Press.

Teeuw, A and D.K. Wyatt. (1970). Hikayat Patani. Bibliotheca Indonesia 5. The Hague: Martinus Nijhoff. Wiyatmi. (2013). Sosiologi Sastra. Yogyakarta: Kanwa Publisher.

Yock Fang, Liaw. (20I I). Sejarah Kesusastraan Melayu Klasik. Jakarta: Yayasan Pustaka Obor Indonesia.

Yusuf, A.Muri. (2007). Metodologi Penelitian. Padang: UNP Press. 